\title{
INVENTARISASI TANAMAN OBAT TRADISIONAL UNTUK PENGOBATAN TUBERKULOSIS OLEH BATTRA DI WILAYAH KERJA PUSKESMAS KABUPATEN GOWA SULAWESI SELATAN
}

\author{
*)Murniati *)Gerfan Patandung, *)Intan Aryana Putri \\ *)Akademi Farmasi Sandi Karsa Makassar \\ *)Program Studi D-III Farmasi Sandi Karsa Makassar
}

\begin{abstract}
ABSTRAK
Telah dilakukan penelitian mengenai Inventarisasi Tanaman Obat Tradisional Untuk Pengobatan Tuberkulosis Oleh Battra di Wilayah Kerja Puskesmas Kabupaten Gowa Sulawesi Selatan. Tujuan penelitian ini adalah untuk mengetahui tanaman obat tradisional yang digunakan oleh battra di wilayah kerja Puskesmas Kabupaten Gowa Sulawesi Selatan untuk mengobati Tuberkulosis. Cara mengumpulkan data mencakup survei dengan teknik pengumpulan data berupa wawancara. Penelitian ini dilaksanakan di 3 Puskesmas Kabupaten Gowa yaitu Puskesmas Palangga, Puskesmas Kanjilo, dan Puskesmas Gentungan. Hasil penelitian menunjukkan bahwa tanaman obat tradisional yang digunakan oleh battra di wilayah kerja Puskesmas Kabupaten Gowa Sulawesi Selatan adalah daun miana, jeruk nipis, dan daun paliasa.
\end{abstract}

Kata kunci: Tanaman Obat, Battra, Tuberkulosis

\section{PENDAHULUAN}

\section{B. Latar Belakang}

Indonesia termasuk salah satu negara yang kaya akan tanaman obat. Dari sekitar 1.000 jenis tanaman obat, diantaranya lebih dari 300 jenis sangat potensial untuk dimanfaatkan sebagai bahan baku jamu dan obat tradisional. Jamu dan obat tradisional merupakan aset nasional sebagai sarana kesehatan masyarakat secara turun-temurun yang tidak dimiliki oleh bangsa lain (Rukmana,2003).

Pengobatan tradisional sudah ada di Indonesia, jauh sebelum pelayanan kesehatan formal dengan obat-obatan modernnya dikenal masyarakat. Pengobatan tradisional dengan memanfaatkan tumbuhan berkhasiat obat merupakan pengobatan yang dimanfaatkan dan diakui masyarakat dunia, yang menandai kesadaran untuk kembali ke alam (back to nature) adalah untuk mencapai kesehatan yang optimal dan untuk mengatasi berbagai penyakit secara alami (Wijayakusuma,2000).

Obat tradisional telah dikenal dan banyak digunakan secara turun-temurun oleh masyarakat. Umumnya pemanfaatan obat tradisional lebih diutamakan sebagai upaya preventif untuk menjaga kesehatan. Selain itu adapula yang menggunakannya untuk pengobatan suatu penyakit. Dalam pelaksanaannya, diharapkan melibatkan peran aktif seluruh masyarakat dengan bimbingan dan binaan puskesmas setempat (Suharmiati,2008).

Tuberkulosis (TB) adalah suatu penyakit infeksi menular yang disebabkan oleh Mycobacterium tuberculosis, yang dapat menyerang berbagai organ terutama paru-paru. TB diperkirakan sudah ada di dunia sejak 5000 tahun sebelum masehi, namun kemajuan dalam penemuan dan pengendalian penyakit TB baru terjadi dalam dua abad terakhir. Dalam epidemiologi yang melihat kejadian penyakit sebagai hasil interaksi antara tiga kompenen agent, host, dan environment. Pada sisi host, vulnerabilitas terhadap infeksi Mycobacterium tuberculosis sangat di pengaruhi oleh daya tahan tubuh seseorang saat itu (Kemenkes RI,2016).

Dalam laporan WHO tahun 2013 diperkirakan terdapat 8,6 juta kasus TB pada tahun 2012 dimana 1,1 juta orang $(13 \%)$ diantaranya adalah pasien dengan HIV positif. Sekitar $75 \%$ dari pasien tersebut berada di wilayah Afrika. Pada tahun 2012 diperkirakan terdapat 450.000 orang yang menderita TB MDR (multi drug resistence) dan 170.000 diantaranya meninggal dunia. Pada tahun 2012 diperkirakan proporsi kasus TB anak diantara seluruh kasus TB secara global mencapai $6 \%$ atau 530.000 pasien TB anak pertahun atau sekitar $8 \%$ dari total kematian yang disebabkan TB (Kemenkes RI,2016).

Indonesia berpeluang mencapai penurunan angka kesakitan dan angka kematian akibat TB menjadi setengahnya di tahun 2015 jika dibandingkan dengan data tahun 1990. Angka prevalensi TB yang ada pada tahun 1990 sebesar 443 per 10.000 penduduk. Pada tahun 2015 ditargetkan menjadi 280 per 100.000 penduduk. Berdasarkan hasil survei prevalensi TB tahun 2013, prevalensi TB positif per 100.000 penduduk umur 15 tahun keatas sebesar 257 (Kemenkes RI,2016).

Penggunaan secara empiris tanaman obat oleh battra, dewasa ini telah diadakan oleh puskesmas. Salah satu jenis penyakit yang sering diobati oleh battra adalah tuberkulosis. Berdasarkan riset tanaman obat dan jamu tahun 2015, telah disurvey tanaman obat dan jamu di 5 kabupaten yaitu Kabupaten Sinjai, Kabupaten Maros, Kabupaten 
Enrekang, Kabupaten Luwu Utara, Kabupaten Luwu Timur dengan 10 jenis tanaman obat untuk pengobatan tuberkulosis yaitu Curcuma longa L, Curcuma zanthorrhiza Roxb, Zingiber officinale Roscoe, Centella asiatica (L) Urb, Alium sativum L, Citrus aurantifolia (Christm) Swingle, Cocos nucifera L, Kaempferia galanga L, Momordica charantia L, Musa paradisiaca L (Ristoja,2015).

Puskesmas merupakan kesatuan organisasi fungsional yang menyelenggarakan upaya kesehatan yang bersifat menyeluruh, terpadu, merata, dan dapat diterima dan dijangkau oleh masyarakat dengan peran serta aktif masyarakat dan menggunakan hasil pengembangan ilmu pengetahuan dan teknologi tepat guna, dengan biaya yang dapat dipikul oleh pemerintah dan masyarakat luas guna mencapai derajat kesehatan yang optimal, tanpa mengabaikan mutu pelayanan kepada perorangan. Wilayah kerja Puskesmas Kabupaten Gowa Sulawesi Selatan akan menjadi tempat penelitian mengenai inventarisasi tanaman obat tradisional oleh battra di Puskesmas Palangga, Puskesmas Gentungan, dan Puskesmas Kanjilo Kabupaten Gowa Sulawesi Selatan, dan sudah dilakukan observasi sebelumnya. Penelitian yang dilakukan di wilayah kerja Puskesmas Kabupaten Gowa Sulawesi Selatan merupakan tempat yang lebih dekat untuk dilakukan penelitian oleh peneliti.

\section{B. Rumusan Masalah}

Berdasarkan uraian diatas maka rumusan masalah dalam penelitian ini adalah apa sajakah tanaman obat tradisional yang digunakan oleh battra di wilayah kerja Puskesmas Kabupaten Gowa Sulawesi Selatan, khusus untuk mengobati tuberkulosis?

\section{Tujuan Penelitian}

Tujuan dari penelitian ini adalah untuk mengetahui tanaman obat tradisional yang digunakan oleh battra di wilayah kerja Puskesmas Kabupaten Gowa Sulawesi Selatan untuk mengobati tuberkulosis.

\section{Manfaat Penelitian}

Manfaat dari penelitian ini adalah sebagai bahan referensi untuk penelitian selanjutnya mengenai inventarisasi tanaman obat tradisional untuk pengobatan tuberkulosis oleh battra di wilayah kerja Puskesmas Kabupaten Gowa Sulawesi Selatan.

\section{METODE PENELITIAN}

\section{A. Jenis Penelitian}

Jenis penilitian yang akan digunakan adalah deskriptif yaitu penelitian yang memberikan gambaran secara jelas dan sistematis berupa katakata atau kalimat-kalimat mengenai objek yang diteliti untuk memberi informasi dan data yang sah berdasarkan dengan fakta dan fenomena yang ada di lapangan.

\section{B. Tempat dan Waktu Penelitian}

Penelitian ini dilakukan pada bulan Bulan Maret 2019 di wilayah kerja Puskesmas Palangga, Puskesmas Gentungan, dan Puskesmas Kanjilo Kabupaten Gowa Sulawesi Selatan..

\section{Populasi dan Sampel}

a. Populasi

Populasi penelitian adalah pengobat tradisional (battra) yang berada di wilayah kerja Puskesmas Kabupaten Gowa Sulawesi Selatan.

b. Sampel

Battra yang tinggal di wilayah kerja Puskesmas Palangga, Puskesmas Gentungan, dan Puskesmas Kanjilo Kabupaten Gowa Sulawesi Selatan

\section{Pengumpulan dan Pengolahan Data}

a. Pengumpulan data

Pengumpulan data utama dalam penelitian ini menggunakan panduan wawancara. Wawancara yang dilakukan oleh peneliti untuk mengetahui gambaran umum terkait objek penelitian meliputi aspek keberadaan battra, tanaman obat tradisional yang digunakan oleh battra sebagai pengobatan Tuberkulosis di wilayah kerja Puskesmas Palangga, Puskesmas Gentungan, dan Puskesmas Kanjilo Kabupaten Gowa Sulawesi Selatan.

b. Teknik Pengolahan

Data di tabulasi berdasarkan identitas responden (battra) Jenis tanaman yang digunakan, cara menggunakan, bagian tanaman yang digunakan

\section{E. Defenisi Operasional}

a. Inventarisasi tanaman obat adalah pengumpulan data tentang tanaman obat yang digunakan oleh battra di wilayah kerja Puskesmas Kabupaten Gowa Sulawesi Selatan untuk pengobatan tuberkulosis.

b. Battra atau pengobat tradisional adalah adalah orang yang mengetahui tentang tumbuhan obat, meramu obat, dan yang melakukan praktek pengobatan tradisional.

c. Puskesmas Kabupaten Gowa Sulawesi Selatan merupakan suatu bagian operasional pelayanan yang memberikan upaya kesehatan secara terpadu, menyeluruh dalam meningkatkan kesejahteraan dan kesehatan masyarakat disekitarnya. 


\section{HASIL DAN PEMBAHASAN}

\section{A. Hasil Penelitian}

Hasil data yang diperoleh selama penelitian di wilayah kerja Puskesmas Palangga, Puskesmas Kanjilo, dan Puskesmas Gentungan Kabupaten Gowa Sulawesi Selatan adalah sebagai berikut :

1. Identitas Responden :

Tabel I. Identitas Responden

\begin{tabular}{cccccc}
\hline No & $\begin{array}{c}\text { Nama } \\
\text { dan } \\
\text { Umur }\end{array}$ & Alamat & $\begin{array}{c}\text { Pendidikan/ } \\
\text { Pekerjaan }\end{array}$ & $\begin{array}{c}\text { Lama } \\
\text { Menjadi } \\
\text { Battra }\end{array}$ & $\begin{array}{c}\text { Sumber } \\
\text { Informasi } \\
\text { Obat }\end{array}$ \\
\hline 1 & M.R & Sungguminasa & PNS & 1 Tahun & $\begin{array}{c}\text { Penelitian } \\
\text { Saat } \\
\text { Kuliah }\end{array}$ \\
\hline 2 & B & Takalar & PNS & 4 Tahun & BKTM \\
\hline 3 & W.W & $\begin{array}{c}\text { J1.Nuri no.6 B } \\
\text { Mariso }\end{array}$ & PNS & 5 Tahun & $\begin{array}{c}\text { Penelitian } \\
\text { Saat } \\
\text { Kuliah }\end{array}$ \\
\hline & & & & & \\
\hline
\end{tabular}

2. Inventarisasi Tanaman Obat Tabel II. Inventarisasi Tanaman Obat

\begin{tabular}{|c|c|c|c|c|}
\hline Responden & $\begin{array}{c}\text { Jenis } \\
\text { Tanaman/Bagian } \\
\text { Tanaman } \\
\end{array}$ & $\begin{array}{l}\text { Cara } \\
\text { Pakai }\end{array}$ & $\begin{array}{c}\text { Aturan } \\
\text { Lama } \\
\text { Pakai }\end{array}$ & Keterangan \\
\hline M.R & $\begin{array}{c}\text { Daun Paliasa/ } \\
\text { Daun }\end{array}$ & Direbus & $\begin{array}{c}\text { 2x1 } \\
\text { (Selama } \\
\text { Batuk) }\end{array}$ & $\begin{array}{c}\text { Simplisia } \\
\text { Tunggal }\end{array}$ \\
\hline B & $\begin{array}{l}\text { Miana dan Jeruk } \\
\text { Nipis/ Daun dan } \\
\text { Buah }\end{array}$ & $\begin{array}{l}\text { Ditumbuk/ } \\
\text { Diremas }\end{array}$ & $\begin{array}{c}\text { 3x1 } \\
\text { (Selama } \\
\text { Batuk) }\end{array}$ & $\begin{array}{c}\text { Gabungan } \\
\text { Simplisia }\end{array}$ \\
\hline W.W & $\begin{array}{l}\text { Miana dan Jeruk } \\
\text { Nipis/ Daun dan } \\
\text { Buah }\end{array}$ & $\begin{array}{l}\text { Ditumbuk/ } \\
\text { Diremas }\end{array}$ & $\begin{array}{c}3 \times 1 \\
\text { (Selama } \\
\text { Batuk) }\end{array}$ & $\begin{array}{c}\text { Gabungan } \\
\text { Simplisia }\end{array}$ \\
\hline
\end{tabular}

Tabel III. Jenis Tanaman Obat Tradisional Yang di Gunakan Oleh Battra Untuk Pengobatan Tuberkulosis di Wilayah Kerja Puskesmas Kabupaten Gowa Sulawesi Selatan

\begin{tabular}{|c|c|c|c|c|}
\hline No & $\begin{array}{l}\text { Nama Ilmiah/ } \\
\text { Family }\end{array}$ & Khasiat Tanaman & $\begin{array}{l}\text { Bagian } \\
\text { tanaman }\end{array}$ & $\begin{array}{l}\text { Cara } \\
\text { Pemakaian }\end{array}$ \\
\hline 1 & $\begin{array}{l}\text { Miana } \\
\text { (Coleous } \\
\text { scentellarioides } \\
\text { L. Benth) } \\
\text { Lamiacaea }\end{array}$ & $\begin{array}{l}\text { Digunakan dalam } \\
\text { berbagai pengobatan } \\
\text { seperti : postpartum, } \\
\text { dermatitis, sakit perut, } \\
\text { asma, batuk, dan } \\
\text { gangguan pencernaan. }\end{array}$ & Daun & $\begin{array}{l}\text { Daun myana } \\
\text { dicuci bersih } \\
\text { terlebih dahulu } \\
\text { kemudian } \\
\text { diremas atau } \\
\text { ditumbuk, air } \\
\text { perasannya } \\
\text { disaring dan } \\
\text { diminum }\end{array}$ \\
\hline 2 & $\begin{array}{l}\text { Jeruk Nipis } \\
\text { (Citrus } \\
\text { aurantifolia.s) } \\
\text { Rutaceae }\end{array}$ & $\begin{array}{l}\text { Digunakan sebagai } \\
\text { antibakteri, antifungal, } \\
\text { antioksidan dan } \\
\text { antikanker }\end{array}$ & Buah & $\begin{array}{l}\text { Buah jeruk nipis } \\
\text { diambil dan } \\
\text { dicuci bersih, } \\
\text { dan dibelah dua } \\
\text { kemudian di } \\
\text { peras, air } \\
\text { perasannya yang } \\
\text { digunakan }\end{array}$ \\
\hline 3 & $\begin{array}{l}\text { Daun paliasa } \\
\text { (Kleinhovia } \\
\text { hospita L) } \\
\text { Malvaceae }\end{array}$ & $\begin{array}{l}\text { Digunakan sebagai } \\
\text { antikanker, } \\
\text { antidiabetes, } \\
\text { antioksidan,dan } \\
\text { terutama digunakan } \\
\text { sebagai agen } \\
\text { hepatoprotektor }\end{array}$ & Daun & $\begin{array}{l}\text { Daun palaisa } \\
\text { diambil ganjil, } \\
\text { dicuci bersih dan } \\
\text { direbus }\end{array}$ \\
\hline
\end{tabular}

\section{B. Pembahasan}

Pengobatan tradisional adalah pengobatan dan atau perawatan dengan cara pengobatan yang mengacu pada pengalaman dan keterampilan turun temurun. bahan hewan, bahan mineral, sediaan sarian (galenik) atau campuran dari bahan tersebut secara turun temurun telah digunakan untuk pengobatan berdasarkan pengalaman.

Pengobatan tradisional (battra) adalah seseorang yang diakui dan dimanfaatkan oleh masyarakat sebagai orang yang mampu melakukan pengobatan secara tradisional.. Jamu/obat tradisional adalah ramuan tradisional yang berasal dari tumbuh-tumbuhan dan hasil-hasilnya atau hewan dari hasilhasilnya, akar-akaran yang secara tradisional dapat dianggap berkhasiat untuk menyembuhkan penyakit atau untuk memelihara kesehatan.

Berdasarkan observasi di wilayah kerja Puskesmas Kabupaten Gowa Sulawesi Selatan ditemukan ada 3 responden (battra) yang melakukan praktek pengobatan tradisional di Puskesmas. Data dikumpulkan dengan cara mewawancarai battra mengenai tanaman obat tradisional yang digunakan untuk pengobatan tuberkulosis.

Responden (battra) yang berada di Puskesmas Palangga Kabuaten Gowa Sulawesi Selatan sudah 4 tahun menjadi battra di Puskesmas tersebut. Penyakit-penyakit yang sering diobati seperti sesak, batuk, dan nyeri otot, bahkan penyakit seperti tuberkulosis juga pernah diobati dengan menggunakan tanaman obat tradisional. Untuk tanaman obat tradisional yang digunakan battra untuk mengobati penyakit tuberkulosis adalah daun miana dan jeruk nipis. Bagian tanaman yang digunakan yaitu daun miana dan buah jeruk nipis. Cara menggunakan obat tradisional dengan mengambil daun dan dibersihkan terlebih dahulu kemudian diremas dan hasil dari air perasannya diminum. Sedangkan untuk jeruk nipis diambil buahnya kemudian dibersihkan terlebih dahulu lalu dibelah dan diperas airnya, hasil dari perasannya itu diminum. Obat tradisional ini dikonsumsi selama batuk. Sumber dari tanaman obat tersebut berdasarkan informasi dari BKTM (Balai Kesehatan Tradisional Masyarakat).

Battra yang berada di wilayah kerja Puskesmas Kanjilo sudah 5 tahun menjadi seorang pengobat tradisional. Ada beberapa penyakit-penyakit yang sering diobati dengan menggunakan obat tradisional seperti batuk, diare, demam, hipertensi, dan diabetes. Bahkan penyakit tuberkulosis juga pernah diobati dengan obat tradisional. Battra menjelaskan bahwa ada beberapa ciri-ciri atau keluhan dari 
pasien yang datang ke Puskesmas seperti batuk, keringat di malam hari, berat badan menurun. Untuk obat tradisional yang diberikan kepada pasien yang datang adalah daun miana dan buah jeruk nipis. Sedangkan untuk cara meramunya dengan mengambil daun miana dan buah jeruk nipis kemudian dibersihkan terlebih dahulu, daun miana diremas untuk diambil air perasannya dan buah jeruk nipis dibelah dua dan diperas. Obat tradisional yang diberikan kepada pasien dikonsumsi selama batuk. Sumber informasi tentang tanaman tradisional yang digunakan battra dalam pengobatan berdasarkan penelitian pada saat kuliah.

Battra di Puskesmas Gentungan Kabupaten Gowa Sulawesi Selatan sudah 1 tahun menjadi pengobat tradisional. Penyakitpenyakit yang sering diobati dengan obat tradisional seperti penyakit hipertensi dan batuk, bahkan penyakit tuberkulosis juga pernah diobati dengan obat tradisional. Tanaman obat tradisional yang digunakan battra untuk mengobati penayakit tuberkulosis di Puskesmas Gentungan adalah daun paliasa. Battra menjelaskan bahwa cara meramu dari daun paliasa tersebut dengan mengambil daun paliasa sebanyak 7 lembar kemudian dibersihkan terlebih dahulu, setelah bersih lalu direbus dengan 12 gelas air. Rebusan daun paliasa dikonsumsi selama terapi pengobatan obat program tuberkulosis. Sumber informasi tanaman yang diketahui oleh battra untuk mengobati penyakit tuberkulosis berdasarkan penelitian pada saat kuliah.

Tanaman obat tradisional yang digunakan battra seperti daun miana (Coleous scentellarioides L.Benth) dengan nama family lamiacaea atau yang biasa disebut dengan tanaman iler, digunakan dalam pengobatan seperti postpartum, dermatitis, sakit perut, asma, batuk, dan gangguan pencernaan. Senyawa kimia yang terkandung dalam daun miana adalah golongan minyak atsiri, flavanoid, alkaloid, steroid, tanin dan saponin. Tanaman ini yang digunakan sebagai obat adalah bagian daun.

Jeruk nipis (Citrus aurantifolia.Swingle) dengan nama family rutaceae. Bagian-bagian tanaman jeruk nipis dapat dimanfaatkan untuk mengobati berbagai penyakit antara lain batang, bungan, buah, dan daunnya. Buah jeruk nipis banyak digunakan untuk menurunkan panas, obat batuk, peluruh dahak, antiinflamasi, dan antiseptik. Jeruk nipis mengandung unsur-unsur senyawa kimia yang bermanfaat seperti asam sitrat, asam amino, minyak atsiri, damar, glikosida, asam sitrun, lemak, kalsium, fosfor, besi, alkaloid, flavanoid, terpenoid, saponin, tanin, dan steroid. Senyawa-senyawa tersebut memiliki kemampuan untuk menghambat pertumbuhan bakteri dengan mekanisme hambatnya masingmasing.

Pada tanaman obat tradisional daun paliasa (Kleinhovia hospita. L) dengan nama family malvaceae. Tumbuhan ini dikenal juga dengan nama timoho (Jawa) dan paliasa (Bugis). Beberapa komponen yang dapat diisolasi dari daun paliasa antara lain skopoletin, kuarsetin, rutin dan kamferol. Tanaman ini memiliki porensi farmakologis antara lain sebagai antikanker, antidiabetes, antioksidan, dan hepatoprotektif. Bagian tanaman yang digunakan sebagai obat tradisional adalah daun.

\section{PENUTUP}

\section{A. Kesimpulan}

Berdasarkan data yang diperoleh maka dapat disimpulkan bahwa jenis-jenis tanaman yang digunakan oleh pengobat tradisional di wilayah kerja Puskesmas Palangga, Puskesmas Kanjilo, dan Puskesmas Gentungan Kabupaten Gowa Sulawesi Selatan adalah daun miana, jeruk nipis, dan daun paliasa.

\section{B. Saran}

Disarankan melakukan penelitian lebih lanjut untuk membuktikan potensi tanaman sebagai antibakteri tuberkulosis secara in vitro dan in vivo.

\section{DAFTAR PUSTAKA}

Asmino. 1996. Antropologi Kesehatan Indonesia Jilid I Pengobatan Tradisional. EGC; Jakarta.

Kemenkes RI. 2016. Tuberkulosis Temukan Obati Sampai Sembuh. Info Datin; Jakarta.

Kemenkes RI. 2015. Riset Tanaman Obat dan Jamu. Balai Besar Penelitian dan Pengembangan Tanaman Obat dan Obat Tradisional; Jakarta.

Mursito, B. 2006. Ramuan Tradisional Untuk Pelangsing Tubuh. Niaga Suada; Jakarta.

Nurmalina, R. 2012. 24 Herbal Legendaris Untuk Kesehatan Anda. Elex Media Komputindo; Jakarta.

Obi, A. 2015. Penyakit Menular Disekitar Anda. Pustaka Ilmu Semesta; Jakarta.

Gagas, U. 2014. Sehat Alami Dengan Obat Herbal. Gramedia Pustaka Utama; Jakarta. 
Permadi, A. 2008. Membuat Kebun Tanaman Obat. Pustaka Bunda; Jakarta.

Rukmana, R. 2003. Cabai Jawa. Kanisius; Jakarta.

Savitri, A. 2016. Basmi Penyakit Dengan Toga. Bibit Publisher; Jakarta.

Suharmiati. 2008. Cara Benar Meracik Obat Tradisional. Agro Media; Jakarta.

Tjay, H. 2002. Obat-Obat Penting Edisi 5. Elex Media Komputindo; Jakarta.

Utami, P. 2003. Tanaman Obat Untuk Mengatasi Diabetes Melitus. Agro Media; Jakarta.

Wijayakusuma. 2000. Ensiklopedia Milenium. Prestasi Insan Indonesia; Jakarta 